\title{
THE ROLE OF SUPERVISOR AND STUDENT FOR COMPLETING A THESIS
}

\author{
Uma Nath Sharma*
}

\begin{abstract}
Master's degree students are required to write a thesis as a course alternative to a written examination of a paper. The purpose of this article is to understand and discuss the students' perception on their own roles as a thesis candidate and the role of a supervisor in accomplishing a work of master's thesis. For this, the candidates of master's thesis were asked to respond a multiple choice item like questionnaire consisting of 12 sets of statements on the student-supervisor roles or responsibilities in three major aspects of thesis writing, namely topic/area of study, contact/involvement and the thesis/dissertation. The responses were analyzed descriptively using the software package - SPSS (Statistical Package for the Social Sciences). Analysis showed that the average students wanted to build a bridge (plan and manage the thesis writing) together with the supervisor so that they could cross it (accomplish the work of thesis writing). The students expected joint role of a supervisor. The supervisor and the student are recommended to share their expectations from each other, and build a mutual understanding of supervisor-student roles in advance and do accordingly for the successful completion of the thesis in reasonable time.
\end{abstract}

Key words: Supervisor, thesis, candidate, perception, role, responsibility, hands-on supervision, systematic approach.

\section{INTRODUCTION AND OBJECTIVE}

The students of master's degree in Tribhuvan University are required to write a thesis as a course alternative to a written examination of a paper. That is to say, there is a provision of carrying out a research and preparing a report as a thesis to complete the master's degree, though not mandatory. More specifically, the students of M. Ed. English, who are the focus of this study, have to write a thesis related to English language. The medium is also English, which is a second language for Nepali students. There is no provision of regular classes for this course except the research methodology course in language education regarding the specified type of students (i.e., M. Ed. English students). Moreover, some of the students do not attend the theory classes regularly. English, which is the medium of thesis writing, is

* Mr. Sharma is Lecturer in Faculty of Education, Mahendra Ratna Campus, Tahachal, TU. 


\section{THE ROLE OF SUPERVISOR AND STUDENT FOR COMPLETING A THESIS}

not their first or dominant language though they are specializing in English education. In this context, it is often difficult for the students to meet the demands of the kind of writing in a thesis. Regarding the possible difficulty the students have to face, Bhandari (2013) writes:

When the students enter into the process of thesis writing, they find it very difficult, so many of them again go back to the course work. Most of the students spend time not being able to select a title for their research, and whenever they meet their professors, seniors, or experts they ask a title for their research, and thesis (p. 9).

The difficulty lies not only in the task of selecting a topic or title but also in the whole process of writing a research proposal, carrying out the research, and writing a thesis. Davis, Parker, \& Straub (2012, p. 72) have proposed 'a systematic approach' to writing the doctoral dissertation for successful and timely completion of a doctoral dissertation. This approach is equally applicable for completion of a master's thesis in a reasonable time. The systematic approach to completing a doctoral dissertation recommends the following propositions:

- Structuring of the dissertation project can significantly improve performance (by means of topic analyses, proposal documents, plans, schedules, and so on...).

- The student has primary responsibility for the management of the doctoral dissertation project.

- Faculty (advisor and committee) are a scarce resource.

The first proposition maintains that the total work of thesis writing should be well-planned and managed because there is large productivity gap between managed and unmanaged work of thesis writing. The second proposition places responsibility for thesis management on the student. Supervisor and other faculty members can help, but the student should take responsibility. The third proposition means that the faculty are important persons, who are not easily available. The student should follow methods of interaction and presentation that effectively use the time and talents of the advisor or supervisor and committee members. That is to say, it is the task of the student to manage the supervisor. In this context, Single (2010) asserts that:

After you have chosen your adviser, or have had your adviser chosen for you, you have to manage your adviser. You will also have to choose the other members of your dissertation committee and manage them as a group. As you are managing 
your dissertation advisor and your committee members, I want you to keep in mind that your committee members are very busy people and that it is your job to manage your dissertation process (pp. 42-43).

David, Parker, \& Straub (2012) opine though "the student has primary responsibility for the management of the doctoral dissertation project" 2012, ( p. 5), which may be also true for the management of master's thesis, there is some role of a supervisor for the timely completion of a quality thesis. For this, there should be mutual understanding of supervisor-student roles in advance. Paltridge and Starfield (2007) opine that 'hands-on' supervision is essential for second language thesis and dissertation writers. In hands-on supervision, the supervisor and the student jointly construct a bridge so that the student can cross. The student and the supervisor explicitly converse "about mutual expectations, roles and responsibilities" (p. 36) so that both can benefit. The other characteristics of hands-on supervision following them are:

Hands-on supervisors provide more input earlier in the candidature and less input later. They constantly encourage and assist candidates to:

- draft thesis text;

- $\quad$ publish and present their research in journals and conferences;

- go through a number of eterations of thesis and publication drafts.

Hands-on supervosors establish 'consistent and viable relationships' based on the 'achievement of early and lasting agreement between supervisor's and candidate's expectations of each other'. (Paltridge \& Starfield, 2007, pp. 36-37)

Both 'systematic approach' (Davis, Parker, \& Straub, 2012) and 'hands-on supervision' (Paltridge \& Starfield, 2007) assume that there should be mutual understanding of the supervisor-student roles and responsibilities in advance for the accomplishment of a thesis. Understanding and discussing the student's perception on the roles of a supervisor and a thesis candidate in accomplishing a work of master's thesis is a prerequisite for this. Research in this direction provides the supervisor with the basis for negotiation with the student as the candidate of thesis writing. In line with the general objective of understanding and discussing the student's perception on the roles of a supervisor and a thesis candidate for the completion of a master's thesis, the following questions are tried to be solved:

- Who do the students think is responsible in selecting/determining a thesis topic, theoretical framework, appropriate programme of research, and necessary facilities, materials, and support to complete their research? 


\section{THE ROLE OF SUPERVISOR AND STUDENT FOR COMPLETING A THESIS}

- What sort of supervisor-student relationship do they expect?

- What do the students think about the supervisor's role in the successful completion of thesis with appropriate methodology and content in reasonable time?

- What is the implication of the solutions of the above questions?

\section{METHODOLOGY}

In this research, descriptive quantitative case study design has been used. The study is mainly based on primary data. The study group consists of candidates of master's thesis. The relevant data were collected from 20 students attending their thesis-orientation programme (2017) in the Department of English Education, Mahendra Ratna Campus, Tahachal, and Kathmandu. The questionnaire was distributed to all the (26) students present on that day in the programme. Twenty-five students returned the questionnaire. Among them, 2 were incomplete. Three of the completed questionnaires were not used for the study purposively to avoid fraction numbers in statistical results. For the collection of the data, the researcher prepared a multiple choice item like questionnaire (see Appendix) consisting of 12 sets of statements on the student-supervisor roles or responsibilities in three major aspects of planning and management of carrying out research and thesis writing, namely topic/area of study, contact/involvement and the thesis/dissertation. The questionnaire was prepared by modifying the role perception scale based on as given in Paltridge \& Starfield (2007, p. 38).

The researcher being one of the members of the faculty in the concerned department, and also being one of the members responsible in the organization of the thesis orientation programme, he did not have to put any extra effort for building rapport with the concerned authority and the students. He simply informed his purpose to his students in the thesis orientation programme distributing the questionnaire, and requested to respond according to the instruction given. He collected the completed questionnaires immediately. The data were coded, tabulated, and analyzed descriptively using the software package-SPSS (Statistical Package for the Social Sciences).

\section{RESULT AND DISCUSSION}

In this part of the research article, frequency distributions of students' perceptions (or points of view) regarding the supervisor-student roles or responsibilities in various aspects of the work of thesis writing are discussed under different headings corresponding to each set of statements in the questionnaire. 
Responsibility to select a thesis topic. The frequency distribution of students' points of view on responsibility to select a thesis topic (Table 1).

Table 1: Student's Perception on Responsibility to Select a Thesis Topic

\begin{tabular}{|l|l|l|}
\hline Point of view & Frequency & Percent \\
\hline It is the supervisor's responsibility to select a topic. & - & 0.0 \\
\hline $\begin{array}{l}\text { The supervisor is more responsible than the student to } \\
\text { select a topic. }\end{array}$ & - & 0.0 \\
\hline $\begin{array}{l}\text { Both the student and supervisor are equally responsible } \\
\text { to select a topic. }\end{array}$ & 9 & 45.0 \\
\hline $\begin{array}{l}\text { The student is more responsible than the supervisor to } \\
\text { select a topic. }\end{array}$ & 3 & 15.0 \\
\hline It is the student's responsibility to select a topic. & 8 & 40.0 \\
\hline Total & 20 & 100.0 \\
\hline
\end{tabular}

Source: Field survey, 2017.

Altogether 45 percent of the students (9 out of 20) were in favour of equal role of student and supervisor to select a thesis topic. None of them had given the task of selecting a topic solely to the supervisor. Eight of them thought that the student was exclusively responsible to select a thesis topic (Table 1).

Responsibility to choose a theoretical framework. The frequency distribution of students' points of view on supervisor-student responsibility to choose a theoretical framework (Table 2).

Table 2: Student's Perception on Responsibility to Choose a Theoretical Framework

\begin{tabular}{|l|l|l|}
\hline Point of view & Frequency & Percent \\
\hline $\begin{array}{l}\text { It is up to the supervisor to decide which theoretical } \\
\text { frame work is most appropriate. }\end{array}$ & - & 0.0 \\
\hline $\begin{array}{l}\text { The supervisor should decide which theoretical } \\
\text { framework is most appropriate, but the student should } \\
\text { be convinced. }\end{array}$ & 5 & 25.0 \\
\hline $\begin{array}{l}\text { There is equal role of the student and the supervisor in } \\
\text { determining the appropriate theoretical framework. }\end{array}$ & 10 & 50.0 \\
\hline $\begin{array}{l}\text { It is student's right to choose a theoretical framework, } \\
\text { but the supervisor should be convinced }\end{array}$ & 3 & 15.0 \\
\hline $\begin{array}{l}\text { A student has the right to choose a theoretical standpoint } \\
\text { even if it conflicts with that of the supervisor. }\end{array}$ & 2 & 10.0 \\
\hline Total & 20 & 100 \\
\hline
\end{tabular}

Source: Field survey, 2017. 
It is obvisous that half of the students (10 out of 20) were in favour of equal supervisor-student role in determining the appropriate theoretical framework. None of them had leave the task of deciding a theoretical framework to the supervisor alone for a thesis candidate. Two of them thought that a student had exclusive right to choose a theoretical standpoint. Five of the students opined that the supervisor should have greater role in deciding which theoretical framework was most appropriate whereas 3 had given greater role to the student (Table 2).

Responsibility to determine an appropriate programme of research. Students' perceptions on supervisor-student responsibilities to determine an appropriate programme of research and study (Table 3).

Table 3: Student's Perception on Responsibility to Determine anAppropriate Programme of Research and Study

\begin{tabular}{|l|l|l|}
\hline Point of view & Frequency & Percent \\
\hline $\begin{array}{l}\text { A supervisor should direct a student in an appropriate } \\
\text { programme of research and study. }\end{array}$ & 4 & 20.0 \\
\hline $\begin{array}{l}\text { A supervisor should direct a student in an appropriate } \\
\text { programme of research and study considering the } \\
\text { student's needs as far as possible. }\end{array}$ & 13 & 65.0 \\
\hline $\begin{array}{l}\text { A student should be able to work out a schedule and } \\
\text { research programme appropriate to their needs. }\end{array}$ & 3 & 15.0 \\
\hline Total & 20 & 100.0 \\
\hline
\end{tabular}

Source: Field survey, 2017.

It is understood that the majority of the students (13 out of 20) were in favour of cooperative role between a supervisor and a student in determining an appropriate programme of research and study. A student should be directed by the supervisor in an appropriate programme in point of view of 4 students whereas 3 students thought that a thesis candidate could work out a schedule and research programme appropriate to their needs (Table 3 ).

Responsibility for necessary facilities, materials and support. The frequency distribution of students' points of view on the responsibility for all necessary facilities, materials and support to complete the research (Table 4). 
Table 4: Student's Perception on Responsibility for Necessary Facilities, Materials and Support

\begin{tabular}{|l|l|l|}
\hline Point of view & Frequency & Percent \\
\hline $\begin{array}{l}\text { A supervisor should ensure that a student has access to } \\
\text { all necessary facilities, materials and support. }\end{array}$ & 2 & 10.0 \\
\hline $\begin{array}{l}\text { A supervisor cannot ensure but should help the student } \\
\text { to find the necessary facilities, materials and support to } \\
\text { complete the research. }\end{array}$ & 11 & 55.0 \\
\hline $\begin{array}{l}\text { The student must find the necessary facilities, materials } \\
\text { and support to complete their research. }\end{array}$ & 7 & 35.0 \\
\hline Total & 20 & 100.0 \\
\hline
\end{tabular}

Source: Field survey, 2017.

The majority of the students (11) opined that a supervisor could not ensure but should help the student to find the necessary facilities, materials and support to complete the research. There are 2 students at end of supervisory role to ensure that a student had access to all necessary facilities, materials and support. However, 7 (35\%) students thought that it was the thesis candidates' responsibility to find the necessary facilities, materials and support to complete their research (Table 4).

Type of supervisor-student relationship. The frequency distribution of students' points of view on the type of supervisor-student relationship (Table 5).

Table 5: Student's Perception on Type of Supervisor-Student Relationship

\begin{tabular}{|l|l|l|}
\hline Point of view & Frequency & Percent \\
\hline $\begin{array}{l}\text { Supervisor-student relationships are purely professional } \\
\text { and personal relationships should not develop. }\end{array}$ & 3 & 15.0 \\
\hline $\begin{array}{l}\text { Professional relationship is a must; close personal } \\
\text { relationship is neither essential nor harmful for } \\
\text { successful supervision. }\end{array}$ & 13 & 65.0 \\
\hline $\begin{array}{l}\text { Close personal relationships are essential for successful } \\
\text { supervision. }\end{array}$ & 4 & 20.0 \\
\hline Total & 20 & 100.0 \\
\hline
\end{tabular}

Source: Field survey, 2017.

The majority of the students (13 out of 20) perceived that professional relationship was a must, and close personal relationship was neither essential nor harmful for successful supervision. Three students were 
in favour of purely professional supervisor-student relationship whereas 4 of the students had preferred lose personal relationships with the supervisor (Table 5).

Responsibility to initiate meeting. The frequency distribution of students' perception on responsibility to initiate meeting (Table 6).

Table 6: Student's Perception on Responsibility to Initiate Meeting

\begin{tabular}{|l|l|l|}
\hline Point of view & Frequency & Percent \\
\hline A supervisor should initiate meetings with a student. & 2 & 10.0 \\
\hline Either a supervisor or a student can initiate meetings. & 10 & 50.0 \\
\hline A student should initiate meetings with their supervisor. & 8 & 40.0 \\
\hline Total & 20 & 100.0 \\
\hline
\end{tabular}

Source: Field survey, 2017.

As shown in Table 6, 50 percent of the students (10) were in neutral position regarding the supervisor-student roles in initiating meetings. Only 2 of the students were at the end of supervisory role to initiate meetings with a student. Eight students were found at the opposite end i.e., students' responsibility to initiate meetings with their supervisor (Table 6).

Responsibility in the way and pace of working in the research. The students' perception on responsibility in the way of working (Table 7).

Table 7: Responsibility in the Way and Pace of Working in the Research

\begin{tabular}{|l|l|l|}
\hline Point of view & Frequency & Percent \\
\hline $\begin{array}{l}\text { A supervisor should check constantly that a student is on } \\
\text { track and working consistently. }\end{array}$ & 8 & 40.0 \\
\hline $\begin{array}{l}\text { A supervisor should give suggestion, but should not } \\
\text { interfere to the student in their way and pace of working. }\end{array}$ & 11 & 55.0 \\
\hline $\begin{array}{l}\text { Students should have the opportunity to find their own } \\
\text { way without having to account for how they spend their } \\
\text { time. }\end{array}$ & 1 & 5.0 \\
\hline Total & 20 & 100.0 \\
\hline
\end{tabular}

Source: Field survey, 2017. 
The majority of the students (11) had agreed with the co-operative role between a supervisor and a student in the way and pace of working in research. Eight students thought that a supervisor should check constantly that a student was on track and working consistently. There was only one student who opined that students should have the opportunity to find their own way without having to account for how they spend their time (Table 7).

Supervisor's role in supporting or terminating the candidature if they thought that a student is not succeeded. The informants' perception on supervisor's role in supporting or terminating the candidature (Table 8).

Table 8: Student's Perception on Supervisor's Role in Supporting or Terminating the Candidature

\begin{tabular}{|l|l|l|}
\hline Point of view & Frequency & Percent \\
\hline $\begin{array}{l}\text { A supervisor should terminate the candidature if they } \\
\text { think a student will not succeed. }\end{array}$ & 1 & 5.0 \\
\hline $\begin{array}{l}\text { A supervisor should help the student to improve his/ } \\
\text { her capability before terminating the candidature. }\end{array}$ & 9 & 45.0 \\
\hline $\begin{array}{l}\text { A supervisor should support the student regardless of } \\
\text { their opinion of the student's capability. }\end{array}$ & 10 & 50.0 \\
\hline Total & 20 & 100.0 \\
\hline
\end{tabular}

Source: Field survey, 2017.

Altogether 50 percent of the students (10) were found to be in favour of supervisor's support to the students regardless of their opinion of the student's capability. There were 9 students, who also do not like the supervisor terminating the candidature without helping them to improve their capability. There was only one student who thinks a supervisor should terminate the candidature if they thought a student is not succeeded (Table 8).

Decision of the deadline of the thesis. The informants' points of view regarding the supervisor-student role in deciding the deadline of the thesis (Table 9). 


\section{THE ROLE OF SUPERVISOR AND STUDENT FOR COMPLETING A THESIS}

Table 9: Student's Perception on Responsibility to Decide the Deadline of the Thesis

\begin{tabular}{|l|l|l|}
\hline Point of view & Frequency & Percent \\
\hline $\begin{array}{l}\text { A supervisor should ensure that the thesis is finished } \\
\text { within the allocated time. }\end{array}$ & 6 & 30.0 \\
\hline $\begin{array}{l}\text { Time factor should be negotiable between the supervisor } \\
\text { and the candidate. }\end{array}$ & 13 & 65.0 \\
\hline $\begin{array}{l}\text { As long as a student works steadily they should be able } \\
\text { to take as long as they need to finish the work. }\end{array}$ & 1 & 5.0 \\
\hline Total & 20 & 100.0 \\
\hline
\end{tabular}

Source: Field survey, 2017.

The majority of the students (13) opined that time factor should be negotiable between the supervisor and the candidate. Six of them believe on the supervisory role to ensure that the thesis is finished within the allocated time. There was only one informant, who thought that as long as a student works steadily they should be able to take as long as they needed to finish the work (Table 9).

Responsibility for the selection of methodology and content of the thesis. The perception of the informants regarding the responsibility for the selection of methodology and content of the thesis (Table 10).

Table 10: Student's Perception on Responsibility for Selection of Methodology and Content

\begin{tabular}{|l|l|l|}
\hline Point of view & Frequency & Percent \\
\hline $\begin{array}{l}\text { A supervisor has direct responsibility for the } \\
\text { methodology and content of the thesis. }\end{array}$ & - & 0.0 \\
\hline $\begin{array}{l}\text { Both the student and the supervisor are equally } \\
\text { responsible for the methodology and content of the } \\
\text { thesis. }\end{array}$ & 15 & 75.0 \\
\hline $\begin{array}{l}\text { A student has total responsibility for ensuring that the } \\
\text { methodology and content of the thesis are appropriate } \\
\text { to the discipline. }\end{array}$ & 5 & 25.0 \\
\hline Total & 20 & 100.0 \\
\hline
\end{tabular}

Source: Field survey, 2017. 
Three fourth of the informants (15) opined that both the student and the supervisor were equally responsible for the methodology and content of the thesis. Five informants were found to be expressed their views that a student was fully responsible for ensuring that the methodology and content of the thesis were appropriate to the discipline. None of the informants were in favour of supervisor's direct responsibility for the selection of methodology and content of the thesis (Table 10).

Responsibility for the flawless presentation of the thesis. The students' points of view on responsibility for the flawless presentation of the thesis (Table 11).

Table 11: Student's Response on Responsibility for the Flawless Presentation of the Thesis

\begin{tabular}{|l|l|l|}
\hline Point of view & Frequency & Percent \\
\hline $\begin{array}{l}\text { A supervisor should assist in the actual writing the } \\
\text { thesis if the student has difficulties, and should ensure } \\
\text { that the presentation is flawless. }\end{array}$ & 1 & 5.0 \\
\hline $\begin{array}{l}\text { A supervisor is also at least partially responsible for the } \\
\text { flawless presentation of the thesis. }\end{array}$ & 15 & 75.0 \\
\hline $\begin{array}{l}\text { A student must take full responsibility for presentation } \\
\text { of the thesis, including grammar and spelling. }\end{array}$ & 4 & 20.0 \\
\hline Total & 20 & 100.0 \\
\hline
\end{tabular}

Source: Field survey, 2017.

Three forth of the informants (15) believed that both the supervisor and the thesis candidate are partially responsible for the flawless presentation of the thesis. Four of them were in favour of full responsibility for presentation of the thesis, including grammar and spelling. There was only one informant, who believed that a supervisor should assist in the actual writing the thesis if the student had difficulties, and should ensure that the presentation is flawless should be (Table 11).

Role of supervisor in giving feedback. The perceptions of informants on the role of supervisor in giving feedback (Table 12). 


\section{THE ROLE OF SUPERVISOR AND STUDENT FOR COMPLETING A THESIS}

Table 12: Student's Perception on Role of Supervisor in Giving Feedback

\begin{tabular}{|l|l|l|}
\hline Point of view & Frequency & Percent \\
\hline $\begin{array}{l}\text { A supervisor should insist on seeing drafts of every } \\
\text { section of the thesis in order to give students feedback } \\
\text { on their work. }\end{array}$ & 6 & 30.0 \\
\hline $\begin{array}{l}\text { A student should ask for feedback on their work even } \\
\text { if the supervisor does not insist on. }\end{array}$ & 10 & 50.0 \\
\hline $\begin{array}{l}\text { It is up to a student to ask for feedback from their } \\
\text { supervisors. }\end{array}$ & 4 & 20.0 \\
\hline Total & 20 & 100.0 \\
\hline
\end{tabular}

Source: Field survey, 2017.

Half of the informants (10) opined that a student should ask for feedback on their work even if the supervisor did not insist on. Six of them believe that a supervisor should insist on seeing drafts of every section of the thesis in order to give students feedback on their work. Likewise, 4 of the informants thought that it was up to a student to ask for feedback from their supervisors (Table 12).

The implication of all these findings is that the thesis candidates expect a neutral supervisory role or involvement in the thesis writing project. The teachers should be aware of the students' expectations in their supervisory role and relationship. Analyzing the research findings, it can be understood that the majority of students were in favour of the neutral/ middle path regarding the supervisor-student role in almost all of the aspects of the work of thesis writing. There was only one aspect, namely supervisor's role in supporting or terminating the candidature if they thought that a student is not succeeded, whereas half of the students (10) were against the excessive role of supervisor in terminating the candidature if they thought a student is not succeeded as shown in Table 8. In other words, they believed that a supervisor should support the student regardless of their opinion of the student's capability. It is quite natural that nobody wants to dig their own grave. Apart from this, majority of the students had accepted the middle path indicating that they wanted to work out the thesis writing project as a joint venture with their supervisor. To be acquainted with such a tendency of students in general is important or helpful for a supervisor to understand their expectations, which could be the basis for 
further negotiation/discussion with the students in the matter. Though some of the students believed on the dominant role of a supervisor or of a student as a thesis candidate in some aspects of thesis writing project, majority of them believed on joint involvement of a supervisor and a candidate.

Thus, the results indicate that the students want to construct the bridge of thesis writing process together with their supervisor so that they can cross it. The results or findings of this research could be the basis for the hands-on supervision, where "the aims and expectations of candidature should be articulated and agreed upon by both parties [( supervisor and candidate)] early on" (Paltridge, \& Starfield, 2007, p. 39). The findings of this research reveals that the expectations of thesis candidates in general, which a supervisor should be familiar with. However, the findings of this study cannot be generalized to each individual. Moreover, thesis supervising usually does not take place in group unlike teaching. Therefore, a supervisor should develop a questionnaire of their own to find out the student's expectations or perceptions regarding the supervisor-student roles or responsibilities in the accomplishment of a thesis. Then the supervisor can also share his/her expectation on the matter. They should discuss substantially "to build a trusting and respectful relationship" (Paltridge \& Starfield, 2007, p. 39), and also to build a mutual understanding of supervisor-student roles in advance for the successful completion of the thesis in reasonable time.

\section{CONCLUSION}

The bridge for a student to cross in course of the journey of their work of thesis writing should be jointly constructed by the student and the supervisor on the basis of the mutual understanding of their respective roles in the completion of the work built in advance. In other words, the task of writing a thesis is a difficult time-consuming and effort-demanding journey that requires joint involvement of the supervisor and thesis candidate with pre-determined roles and responsibilities. 
APPENDIX

\begin{tabular}{|c|c|}
\hline \multicolumn{2}{|c|}{ Topic/area of study } \\
\hline $\begin{array}{l}\text { Set } \\
\text { No. }\end{array}$ & Statements and Code Numbers \\
\hline 1 & $\begin{array}{l}\text { It is the supervisor's responsibility to select a topic. -1 } \\
\text { The supervisor is more responsible than the student to select a topic. - } 2 \\
\text { Both the student and supervisor are equally responsible to select a topic. } \\
\text { - } 3 \\
\text { The student is more responsible than the supervisor to select a topic. - } 4 \\
\text { It is the student's responsibility to select a topic. - } 5\end{array}$ \\
\hline 2 & $\begin{array}{l}\text { It is up to the supervisor to decide which theoretical frame work is most } \\
\text { appropriate. - } 1 \\
\text { The supervisor should decide which theoretical frame work is most } \\
\text { appropriate, but the student should be convinced. - } 2 \\
\text { There is equal role of the student and the supervisor in determining the } \\
\text { appropriate theoretical framework. - } 3 \\
\text { It is the student's right to choose a theoretical framework, but the } \\
\text { supervisor should be convinced. - } 4 \\
\text { A student has the right to choose a theoretical standpoint even if it } \\
\text { conflicts with that of the supervisor. - } 5\end{array}$ \\
\hline 3 & $\begin{array}{l}\text { A supervisor should direct a student in an appropriate programme of } \\
\text { research and study. - } 1 \\
\text { A supervisor should direct a student in an appropriate programme of } \\
\text { research and study considering the student's needs as far as possible. - } 2 \\
\text { A student should be able to work out a schedule and research programme } \\
\text { appropriate to their needs. }-3\end{array}$ \\
\hline 4 & $\begin{array}{l}\text { A supervisor should ensure that a student has access to all necessary } \\
\text { facilities, materials and support. - } 1 \\
\text { A supervisor cannot ensure but should help the student to find the } \\
\text { necessary facilities, materials and support to complete the research. - } 2 \\
\text { The student must find the necessary facilities, materials and support to } \\
\text { complete their research. }-3\end{array}$ \\
\hline
\end{tabular}

\begin{tabular}{|l|l|}
\hline \multicolumn{2}{|l|}{ Contact/involvement } \\
\hline $\begin{array}{l}\text { Set } \\
\text { No. }\end{array}$ & Statements and Code Numbers \\
\hline & $\begin{array}{l}\text { Supervisor-student relationships are purely professional and personal } \\
\text { relationships should not develop. -1 } \\
\text { Close personal relationships are neither essential nor harmful for } \\
\text { successful supervision. - 2 } \\
\text { Close personal relationships are essential for successful supervision. - } 3\end{array}$ \\
\hline
\end{tabular}




\begin{tabular}{|l|l|}
\hline 6 & $\begin{array}{l}\text { A supervisor should initiate meetings with a student. - 1 } \\
\text { Either a supervisor or a student can initiate meetings. - 2 } \\
\text { A student should initiate meetings with their supervisor. - 3 }\end{array}$ \\
\hline 7 & $\begin{array}{l}\text { A supervisor should check constantly that a student is on track and } \\
\text { working consistently. - 1 } \\
\text { A supervisor should give suggestion, but should not interfere to the } \\
\text { student in their way and pace of work. - 2 } \\
\text { Students should have the opportunity to find their own way without } \\
\text { having to account for how they spend their time. - 3 }\end{array}$ \\
\hline 8 & $\begin{array}{l}\text { A supervisor should terminate the candidature if they think a student } \\
\text { will not succeed. - 1 } \\
\text { A supervisor can deny supervising the candidate, but should not } \\
\text { terminate the candidature if they think a student will not succeed. - 2 } \\
\text { A supervisor should support the student regardless of their opinion of } \\
\text { the student's capability. - 3 }\end{array}$ \\
\hline
\end{tabular}

\begin{tabular}{|l|l|}
\hline \multicolumn{2}{|l|}{ The thesis/dissertation } \\
\hline Set No. & Statements and Code Numbers \\
\hline 9 & $\begin{array}{l}\text { A supervisor should ensure that the thesis is finished within the } \\
\text { allocated time. - } 1 \\
\text { Time factor should be negotiable between the supervisor and the } \\
\text { candidate. - 2 } \\
\text { As long as a student works steadily they should be able to take as } \\
\text { long as they need to finish the work. - 3 }\end{array}$ \\
\hline 10 & $\begin{array}{l}\text { A supervisor has direct responsibility for the methodology and } \\
\text { content of the thesis. - 1 }\end{array}$ \\
$\begin{array}{l}\text { Both the student and the supervisor are equally responsible for the } \\
\text { methodology and content of the thesis. - 2 } \\
\text { A student has total responsibility for ensuring that the methodology } \\
\text { and content of the thesis are appropriate to the discipline. -3 }\end{array}$ \\
\hline 11 & $\begin{array}{l}\text { A supervisor should assist in the actual writing of the thesis if the } \\
\text { student has difficulties, and should ensure that the presentation is } \\
\text { flawless. - 1 } \\
\text { A supervisor is also at least partially responsible for the flawless } \\
\text { presentation of the thesis. - 2 } \\
\text { A student must take full responsibility for presentation of the thesis, } \\
\text { including grammar and spelling. - 3 }\end{array}$ \\
\hline $\begin{array}{l}\text { A supervisor should insist on seeing drafts of every section of the } \\
\text { thesis in order to give students feedback on their work. - 1 } \\
\text { A student should ask for feedback on their work even if the supervisor } \\
\text { does not insist on. - 2 } \\
\text { It is up to a student to ask for feedback from their supervisors. - 3 }\end{array}$ \\
\hline
\end{tabular}




\section{WORKS CITED}

Bhandari, B. M. (2013). Where do titlies come from? Tribhuvan University Journal , 28 (1-2), pp. 9-16.

Davis, G. B., Parker, C. A., \& Straub, D. W. (2012). Writing the doctoral dissertation: A systematic approach. New York: Barrons.

Paltridge, B., \& Starfield, S. (2007). Thesis and dissertation writing in a second language: A handbook for supervisors. London: Routledge.

Single, P. B. (2010). Demystifying dissertation writing. Virginia: Stylus Publishing. 